\title{
How to teach an old dog new tricks: a new approach on dating unstratified archaeological features from outdated excavations
}

\author{
Julia Rabitsch $^{1} \cdot$ Ruth Irovec $^{1} \cdot$ Martin Auer ${ }^{1}$ \\ Received: 7 November 2019 / Accepted: 25 February 2020 /Published online: 9 March 2020 \\ (C) The Author(s) 2020
}

\begin{abstract}
When analysing past excavations, the possible lack of information on stratigraphy of small finds can lead to difficulties in dating features of settlements such as building periods or destruction layers. While there can be many factors, the most common reasons are outdated excavation methods, lost written documentation or problems in storage. Studying the material from excavations at the so-called `Gmeinerwiese` in Brigantium/Bregenz, Austria undertaken in 1974 suffered from a combination of these causes, which led to a lack of sound stratigraphical information. However, adapting techniques commonly used for numismatic analyses enabled the gathering of sufficient information to gain a better understanding of the sites' building periods. Furthermore, an approximate date of the buildings' destruction by fire could be obtained. Additionally, a second case study was undertaken using stratified and already analysed findings from Aguntum in Eastern Tyrol, Austria to verify the proposed methodology. The results are consistent with the stratigraphic evaluation, which indicates the functionality of this method.
\end{abstract}

Keywords Graphical dating method $\cdot$ Chronology $\cdot$ Analysing unstratified finds $\cdot$ Material culture studies

\section{Introduction and background}

As part of a study focussing on Rome's internal frontiers $^{1}$, an excavation undertaken in 1974 at the so-called >Gmeinerwiese in the Roman settlement Brigantium/ Bregenz (Austria) (Fig. 1), situated at the shores of Lake Constance, was analysed. In contrast to contemporary excavations, heavy equipment, such as bulldozers

\footnotetext{
1 „Limites inter Provincias - Rome's internal frontiers. An international research project situated at the Universities of, Zurich $(\mathrm{CH})$, Freiburg i. Bg. (D) and Innsbruck (A). The Austrian part of the project was financed by the Austrian Research Fund (FWF-project number: I-1161-G19).
}

Julia Rabitsch

julia.rabitsch@uibk.ac.at

Ruth Irovec

ruth.irovec@uibk.ac.at

Martin Auer

martin.auer@uibk.ac.at

1 Department of Archaeologies, University of Innsbruck, Langer Weg 11, 6020 Innsbruck, Austria and excavators, were used to open up eight trenches on an area of $900 \mathrm{~m}^{2}$ - each $60-80 \mathrm{~m}$ long and $2 \mathrm{~m}$ in width and depth (Fig. 2). Additional trenches were excavated mainly manually in areas where stone buildings could be located. General stratigraphical information was only scarcely documented. While the numerous small finds unearthed in the long trenches only were labelled according to the trench they were recovered from, many small finds that were unearthed during the manual excavations were at least allocated to "inside" or "outside" a building. In some cases, schematic drawings provided additional information on the artefact's position in the trench. Upon completion of the excavations, the small finds were stored in the depot of the vorarlberg museum (formerly known as Vorarlberger Landesmuseum), with a great number of the artefacts still unwashed. Several years later, the remainder of the finds was finally cleaned and inventoried. However, poor storage in the first place had led to confusion regarding the labels. Many labels containing information on a find's location were no longer assignable to the artefacts while other labels were lost at all.

All those issues render contextual analysis almost impossible. Nevertheless, gaining as much information 


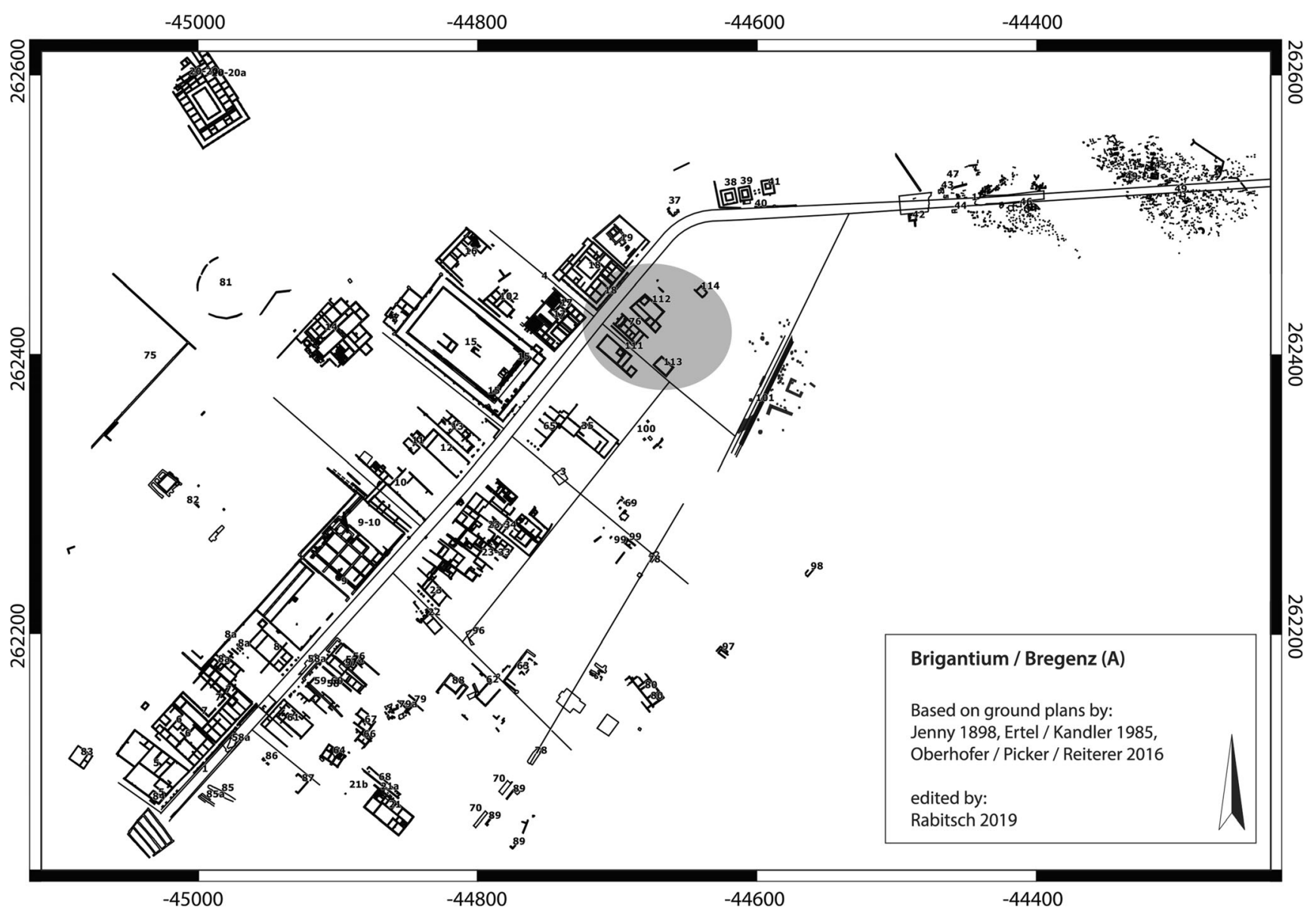

Fig. 1 Map of the known structures of the Roman settlement Brigantium/Bregenz. The area highlighted in grey marks the excavations on the 'Gmeinerwiese

as possible from such excavations is still imperative. Other outdated and poorly documented excavations could certainly benefit from a successful attempt at salvaging information.
Fig. 2 Three of the eight trenches that were dug with the excavators. (photo: vorarlberg museum)

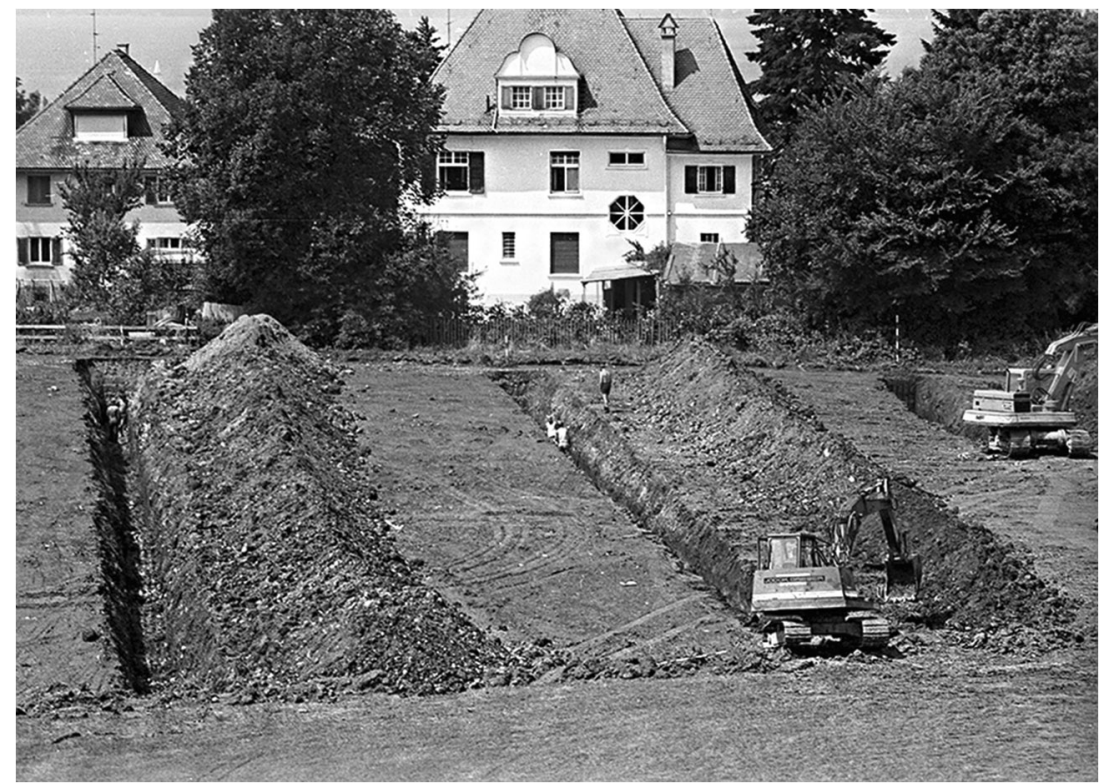




\section{Methodology}

Due to poor recording during the excavation at the >Gmeinerwiese $<$ and problems in storage, only little information was present to work with in the first place. Since it was not possible to connect the little stratigraphy documented with the unearthed small finds in a "traditional" way, it was decided to study the stratigraphy and the small finds separately. The aim was to adapt a method to quantify information still contained by unstratified small finds. The approach used to gain more information on the development of a settlement with only little records present is adapted from numismatic analyses (Vondrovec 2005). This method is presented below using Samian Ware from the 1974 excavation as a sample case. However, all different find categories can be analysed using the following steps.

To analyse Samian Ware, the sample first is prepared: Only vessels with known date or date-range of production are used, while others are excluded to minimise blurring. While plain but stamped ware can be dated using literature, such as Hartley and Dickinson's Names on Terra Sigillata (Hartley and Dickinson 2008a; b; c; 2009a; b; 2010; 2011a; b; 2012), unstamped vessels or vessels with no stamp preserved still can provide a considerable amount of information. First, the unstamped plain vessels are sorted using a typological approach, thus, gaining a rough range of production. Then, using information on the location of production for each vessel, the date-range usually can be tightened further. In case of decorated vessels, typology of the decorative stamps was similarly used as the potter's stamps on the plain ware (e.g. Heiligmann 1990; Planck 1975; Ricken and Fischer 1963; Stanfield and Simpson 1958). To illustrate the obtained data on the decorated and plain vessels, a numeric approach in connection with graphs was established to present the results more comprehensibly and therefore minimising possible errors in their interpretation. As in numismatic analyses, each coin or in this case each vessel occupies the same amount of space in the tables and graphs. A coin dated to exactly 1 year $(1 \times 1)$ will occupy the same space as a find that can be assigned an 8-year span $(8 \times 1 / 8)$. This approach is explained below using an example.

Many Drag. 37 artefacts which were pottered in La Graufesenque were too fragmented to be categorised using their decoration. However, the following is known about those vessels:

- Drag. 37 were produced from late Neronian times to the second half of the third century (Oswald and Pryce 1920).

- Production of Drag. 37 vessels in La Graufesenque commenced in Tiberian times and lasted up to $120 \mathrm{AD}$ (Brulet et al. 2010; Polak 2000; Mees 1995).

- Using this information, it can be stated that the artefacts in question were made between late Neronian times and $120 \mathrm{AD}$.
To analyse and illustrate the results, a timeline with an interval of 5-year steps is created. A quotient is calculated using the date of production and the number of identified specimens (NISP) of a specific vessel type. Using the same case from above:

- 166 fragments of decorated finds produced in La Graufesenque could not be dated further due to fragmentation and therefore range from late Neronian to $120 \mathrm{AD}$.

- Since 5-year steps were chosen as an interval, the year 65 AD is used to mark "late Neronian".

- 65-120 AD consists of eleven 5-year steps.

- 166 finds divided by the eleven 5-year steps results in a quotient of 15.091 (Table 1, highlighted).

- This quotient is then inserted into a table for every 5-year step between 65 and $120 \mathrm{AD}$ and summed up with other quotients for each step and vessel type (Table 2).

The resulting table then was used to produce a diagram, illustrating the number of encountered decorated and plain specimens in 5-year steps between $20 \mathrm{BC}$ and $265 \mathrm{AD}$ (Fig. 3). Therefore, using this approach, it was possible to gain a considerable amount from mainly unstratified Samian finds. For example, the early (Italian) vessels are only rarely present. An increase in Samian Ware is visible with start of production in La Graufesenque. In Neronian and Flavian times, the Samian Ware reaches its peak, only to decrease severely with the end of production in La Graufesenque. After that, the numbers of encountered specimens decrease further, but more steadily. The peak in decorated vessels in Neronian times can be explained by the appearing of Drag. 37, which was exported in great numbers. While this diagram mainly illustrates the date of production of different vessel types, the actual "life span" of these artefacts remains unknown. These steps were undertaken for all the small finds and results were combined. Since the quantities of datable finds vary greatly within the categories - especially with the Samian Ware of which even small fragments can be dated quite accurately - it is advisable to convert the quotients into percentage shares of the total quantity. This way, the different categories can be compared with each other more easily (see Results of the case study with unstratified finds).

\section{Case study with unstratified findings}

As mentioned before, this method was developed or adapted using the findings from the excavations at the \Gmeinerwiese $\prec$ The site is part of the Roman Imperial settlement Brigantium which is set on a 30 ha area of a natural plateau, the ১Ölrain<. This plateau was the main settlement area from the Early Imperial times until the third century 
Table 1 Example of resulting quotient - calculated using information on date of production and number of identified specimens (NISP)

\begin{tabular}{|c|c|c|c|c|c|c|}
\hline \multirow[t]{2}{*}{ Type of vessel } & \multicolumn{2}{|c|}{ La Graufesenque } & \multicolumn{2}{|c|}{ Banassac } & \multicolumn{2}{|c|}{ South Gaul } \\
\hline & NISP & Quotient & NISP & Quotient & NISP & Quotient \\
\hline Drag. 30 no style assigned & 11 & 0.786 & & & 5 & 0.357 \\
\hline Drag. 30 style 1 & 4 & 0.571 & & & & \\
\hline Drag. 30 style 2 & 8 & 0.667 & & & 1 & 0.083 \\
\hline Drag. 37 no style assigned & 166 & 15.091 & 65 & 5.417 & 16 & 0.941 \\
\hline Drag. 37 style 1 & 25 & 3.125 & 3 & 1 & 1 & 0.125 \\
\hline Drag. 37 style $1 / 2$ & 16 & 1.455 & 4 & 0.667 & & \\
\hline Drag. 37 style 2 & 42 & 4,2 & 3 & 0.5 & 1 & 0.1 \\
\hline Drag. 37 style 3 & 8 & 1 & 32 & 5.333 & 1 & 0.125 \\
\hline
\end{tabular}

AD. A second residential area can be located near the Roman harbour at the Lake. From the middle of the first or at least from the second century on, this harbour quarter became more important. Here, continuity can be proven until the sixth century AD. The study of the features documented in this area resulted in at least three building periods: An early one consisting of wooden buildings, two phases of stone buildings and several additional minor rebuilding and/or renovation phases (Rabitsch 2020). These buildings form the northeastern periphery of the Roman settlement. Further, a layer of destruction could be identified, dating after the wooden structures and earlier than the stone buildings.

The findings were analysed by category, each classified by material and function, Samian Ware, amphorae, coarse ware, lamps, brooches, jewellery, tools, coins etc., and analysed separately. The results of these evaluations show that the findings, and therefore the usage of this part of the settlement, date from the early first century until the middle (or maybe the end) of the third century AD. To combine the results, it was necessary to compare the different material culture studies with each other to get a more detailed dating range and in a second step to connect the results with those provided by the study of the features.

Using the aforementioned method, we created a single graph for each of the five significant types of finds, in our case plain Samian Ware, decorated Samian Ware, thin-walled vessels, amphorae and fibulae, and overlaid them to see overall tendencies (Fig. 4). Since the timeline was pre-established from the beginning of Roman Imperial times until the end of the third century, possible earlier and later dates of some findings are not shown in this graph. Even though some of the peaks are a result of the problems discussed hereafter, these graphs provide important information about the development of this area of the settlement. To get significant results, the peaks and troughs were not only compared with the postulated building periods but also reconciled with the known settlement development of Brigantium according to the results of modern excavations.
The Roman settlement originated in three consecutive military forts, the first one dates in Augustan times, the following two in Tiberian times, in the southwestern part of the later town (Kopf 2015). A vicus of traders and craftsmen was built next to the campsite. However, when this vicus was built and when it reached its maximum extension was not known so far. Even though there is proof of some findings dating in to Augustan times, the first peak can be seen in Tiberian times, concluding that this early vicus reached the north-eastern most part of the plateau around that time. The next peak occurs in Claudian times and correlates with the dismantling of the military camp. Around that time, the Roman Army moved further north, and the settlement was reorganised as a civil settlement (Kopf and Oberhofer 2016). The area of the former camp was rededicated as public and residential area, and in this context, the Roman main road was renewed. These large construction activities are reflected by the findings since extended areas were levelled with the debris of demolished buildings and waste such as broken pottery. The wooden house structures seem to belong to these two early major building periods in Brigantium/Bregenz.

The largest peak occurs around the Year of the Four Emperors which can be linked to the already repeatedly postulated and partly proven destruction of the settlement during the turmoil of the civil wars (Grabher 1994; Kopf and Oberhofer 2014; Overbeck 1982). When looking at the features, this peak correlates with a layer consisting of debris, burnt loam and charcoal. This layer together with the high amount of finds, which can be limited to a small period of time, provides a strong indication for a sudden and catastrophic event. Following this destruction, the rubble including the surrounding household items was used for levelling the ground in order to make the area suitable for building again. From there on, a constant decrease can be noted in the dating graphs. This decrease is explained by three factors: First there is a gradual decline of Brigantium's population, either by moving within the settlement (maybe close to the harbour) or by moving to another town or place at all. Second, in an active 
Table 2 Extract of combined calculated raw data using Samian Ware found at the `Gmeinerwiese

\begin{tabular}{|c|c|c|c|c|c|c|c|c|}
\hline \multirow[t]{2}{*}{ Timeline } & \multicolumn{8}{|c|}{ Type of vessel } \\
\hline & Drag. 29 & Drag. 30 & Drag. 37 & Déch. 67 & Knorr 78 & Vind. 13 & Consp. 4 & Consp. 12 \\
\hline \multicolumn{9}{|l|}{-20} \\
\hline-15 & & & & & & & & 1.67 \\
\hline-10 & & & & & & & 0.25 & 1.92 \\
\hline-5 & & & & & & & 0.25 & 1.92 \\
\hline 0 & & & & & & & 0.25 & 1.92 \\
\hline 5 & & & & & & & 0.25 & 1.92 \\
\hline 10 & & & & & & & & 2.67 \\
\hline 15 & 8.296 & & & & & 0.5 & & \\
\hline 20 & 8.296 & & & & & 0.5 & & \\
\hline 25 & 8.296 & & & & & & & \\
\hline 30 & 10.896 & 1.357 & & & & & & \\
\hline 35 & 10.896 & 1.357 & & & & & & \\
\hline 40 & 20.31 & 1.357 & & & & & & \\
\hline 45 & 20.621 & 1.357 & & & & & & \\
\hline 50 & 20.821 & 1.357 & & & & & & \\
\hline 55 & 23.321 & 2.107 & & & & & & \\
\hline 60 & 23.488 & 2.107 & & 0.778 & & & & \\
\hline 65 & 35.988 & 2.678 & 24.896 & 0.778 & & & & \\
\hline 70 & 24.288 & 2.678 & 30.396 & 0.778 & 0.222 & & & \\
\hline 75 & 10.874 & 2.82 & 30.681 & 0.778 & 0.222 & & & \\
\hline 80 & 7.274 & 2.82 & 28.131 & 0.778 & 0.222 & & & \\
\hline 85 & 8.107 & 2.82 & 28.131 & 0.778 & 0.222 & & & \\
\hline 90 & & 2.82 & 41.048 & 1.111 & 0.222 & & & \\
\hline 95 & & 4.82 & 41.048 & 1.111 & 0.222 & & & \\
\hline 100 & & 2.82 & 42.788 & 2.111 & 0.222 & & & \\
\hline 105 & & 1.106 & 38.538 & & 0.222 & & & \\
\hline 110 & & 1.106 & 38.253 & & 0.222 & & & \\
\hline 115 & & 0.214 & 38.253 & & & & & \\
\hline 120 & & & 12.845 & & & & & \\
\hline 125 & & & 12.845 & & & & & \\
\hline 130 & & & 12.97 & & & & & \\
\hline 135 & & & 13.859 & & & & & \\
\hline 140 & & & 15.762 & & & & & \\
\hline 145 & & & 15.762 & & & & & \\
\hline 150 & & & 10.178 & & & & & \\
\hline 155 & & & 10.178 & & & & & \\
\hline 160 & & & 10.595 & & & & & \\
\hline 165 & & & 10.595 & & & & & \\
\hline 170 & & & 10.137 & & & & & \\
\hline 175 & & & 9.87 & & & & & \\
\hline 180 & & & 8.981 & & & & & \\
\hline 185 & & & 8.981 & & & & & \\
\hline 190 & & & 8.814 & & & & & \\
\hline 195 & & & 8.814 & & & & & \\
\hline 200 & & & 4.051 & & & & & \\
\hline 205 & & & 4.051 & & & & & \\
\hline 210 & & & 3.218 & & & & & \\
\hline
\end{tabular}


Table 2 (continued)

\begin{tabular}{|c|c|c|c|c|c|c|c|c|}
\hline \multirow[t]{2}{*}{ Timeline } & \multicolumn{8}{|c|}{ Type of vessel } \\
\hline & Drag. 29 & Drag. 30 & Drag. 37 & Déch. 67 & Knorr 78 & Vind. 13 & Consp. 4 & Consp. 12 \\
\hline 215 & & & 3.218 & & & & & \\
\hline 220 & & & 3.218 & & & & & \\
\hline 225 & & & 3.218 & & & & & \\
\hline 230 & & & 3.552 & & & & & \\
\hline 235 & & & 3.552 & & & & & \\
\hline 240 & & & 3.427 & & & & & \\
\hline 245 & & & 3.427 & & & & & \\
\hline 250 & & & 3.427 & & & & & \\
\hline 255 & & & 3.427 & & & & & \\
\hline 260 & & & 3.093 & & & & & \\
\hline 265 & & & & & & & & \\
\hline
\end{tabular}

and largely non-destructive settlement phase (e.g. no fires, no armed conflicts), the number of finds within the settlement itself is low since the residents made efforts to dispose their waste outside the inhabited area. And last but not least, after the extended destruction, the settlement was rebuilt in stone with solid floors as proven by the analysis of the findings. Those were much easier to clean than the earthen floors from the former wooden buildings. From there on, the settlement continues steadily until the end of the second century AD. At the end of the second century respectively, the beginning of the third century, a last small decrease can be noted where the percentage of the number of findings falls below $1 \%$. This point in time is considered to mark the ending of the Roman Imperial settlement on the Ölrain-plateau. The fact that the end of the settlement does not correlate with another find peak in the graphs is quite interesting. It suggests an organised relocation of the remaining population to the >Oberstadt ( upper town) a geographically safer site (Kopf 2011) rather than a destruction by Germanic tribes as it had been suggested previously (Ertel and Kandler 1985; Konrad 1997).

These results show that with this method, unstratified finds can provide good information on the general development of a site. Especially major events, such as the beginning of the settlement, longer building periods or destructive events are visible.

\section{Case study with stratified findings}

To test the method with a different material, findings from another settlement were used. This case study was carried out by our colleague Martin Auer applying the method to already evaluated finds and features from the Atrium House
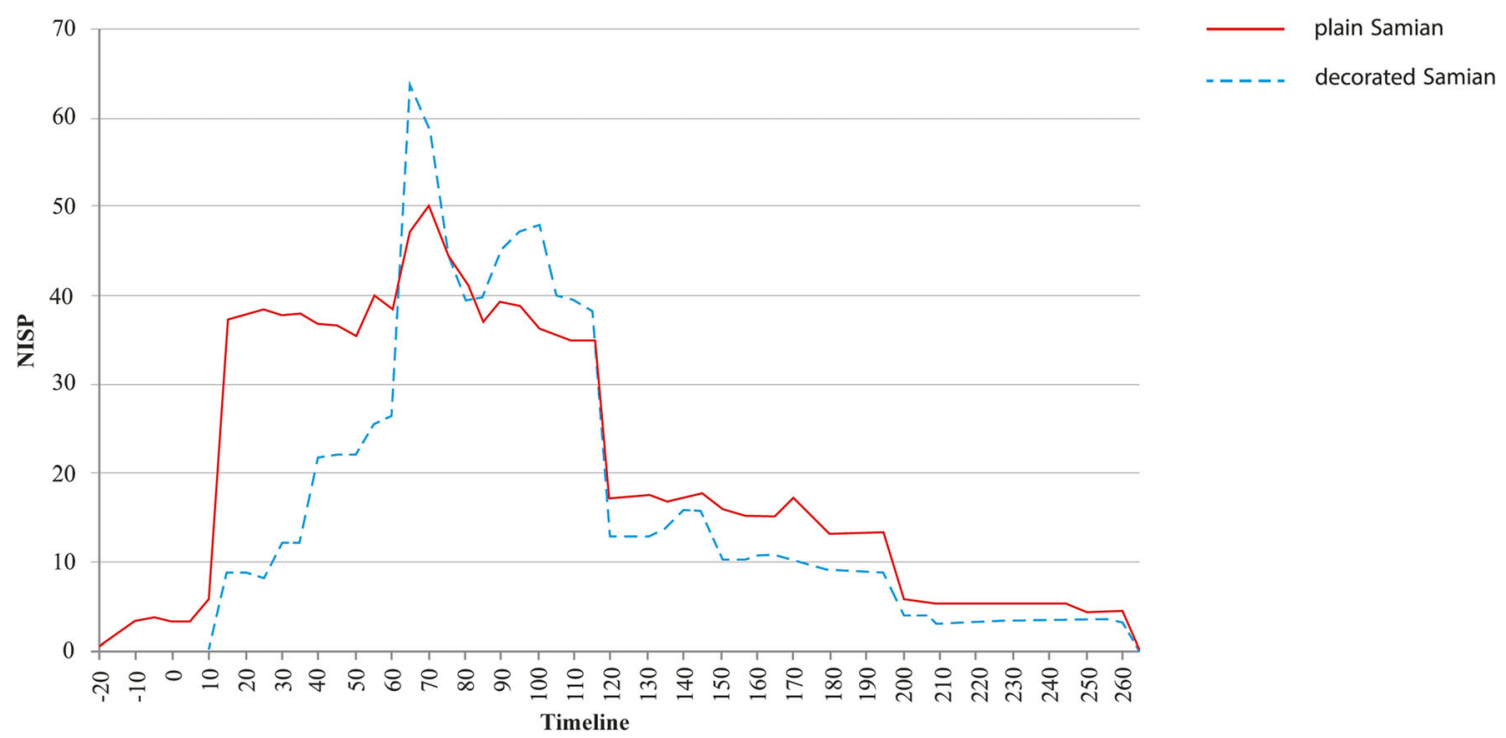

Fig. 3 Quantitative distribution of dated Samian Ware. (created in excel) 


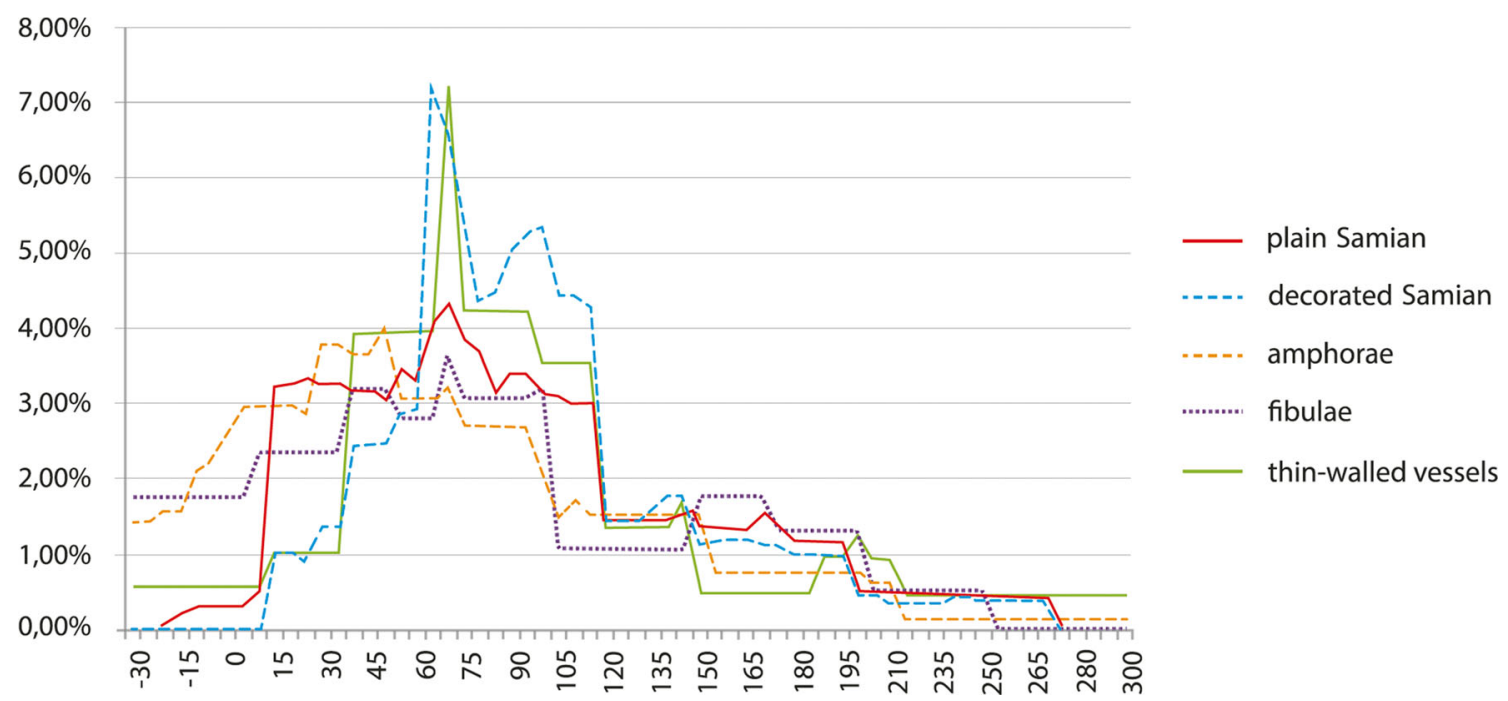

Fig. 4 Result of overlaying the separate graphs (created in excel)

in the municipium Claudium Aguntum (excavations 1994 to 2006).

The Roman municipium Aguntum is located in the southwestern part of the province Noricum, todays Eastern Tyrol in Austria (Fig. 5). Excavations started in the early twentieth century and were continued by the ÖAI (Austrian Archaeological Institute) until 1990. Since 1990, the excavations in Aguntum are carried out by the University of Innsbruck. In the first years, the work of the predecessors was continued; >Haus 1< as part of the Artisan's Quarter and afterwards the so called `Prunkbau<, where excavations had already started under the direction of Wilhelm Alzinger, were researched. The excavations' focus was on the city centre when the >Prunkbau< which is interpreted as part of the Basilica of Aguntum was examined, but due to the replanning of the main transit road in Eastern Tyrol (B 100) that passes straight through the ancient city, this work had to be stopped, and the research focus had to be shifted. In the years 1994 and 1995, excavations around the location line of the road had to be conducted. During these excavations, the central part of the $>$ Atriumhaus` was uncovered (Fig. 6). Due to the rich archaeological remains, including a peristyle with a water basin, paved with big marble plates, the archaeological activity during the following years concentrated on the Atrium House and its surroundings (Tschurtschenthaler 2005).

The long research history of the Atrium House with first excavations in the 1950s and their continuation in the 1990s (for an overview of the research history see Tschurtschenthaler and Auer 2013) results in different qualities of the archaeological documentation. Especially, pottery contexts have not been recorded very well during the earlier excavations. In many cases, we barely know in which room the pottery was found, and detailed context information is completely missing. More recent excavations during the early 1990s unfortunately had the character of rescue excavations. Due to the reconstruction of the modern road, a big area had to be investigated in a relatively short time. Therefore, the fieldwork took place in several smaller and bigger trenches, which is problematic regarding the determination of pottery contexts. Only from 2002 onwards, excavations where conducted as open-area excavations, mainly oriented on ancient features and not that much on artificial trench borders. Therefore, the contextualisation of the pottery is of differing quality, depending on the period and method of excavation. Nevertheless, it is possible to distinguish several phases of the Atrium House, to which the pottery can be assigned.

For this test study only stratified material from the excavations from 1994 to 2006 is used. For the analysis, Samian Ware (799 Imports from Italy, Gaul, Germania and Raetia, the Eastern Mediterranean and Northern Africa), fine, thinwalled vessels (318 imports, mainly from Italy) and amphorae (399 mainly Italian, Istrian and Eastern Mediterranean Imports) were taken into account. As thin-walled vessels and amphorae are very restricted to the first two centuries AD in Noricum, best results emerged when concentrating on Samian Ware.

The first peak in the diagram (Fig. 7) covers the time from $25 \mathrm{AD}$ to $125 \mathrm{AD}$, which corresponds intensive building activity during this period. The Atrium House itself was built around $50 \mathrm{AD}$; towards the end of the first century, this peak reaches its top, which can be connected to the building of heated rooms and the rebuilding of the Eastern Wing of the house in the first half of the second century. During the second half of the second century AD, the curve shows a clear trough which corresponds to the fact that we do not have any traces of building activity during this period. The next peak can be seen around the mid of the third century AD. During this period, the layout of the house underwent serious changes which may be connected to traces of a destruction fire which took place in the first half of the third century AD. These building activities 


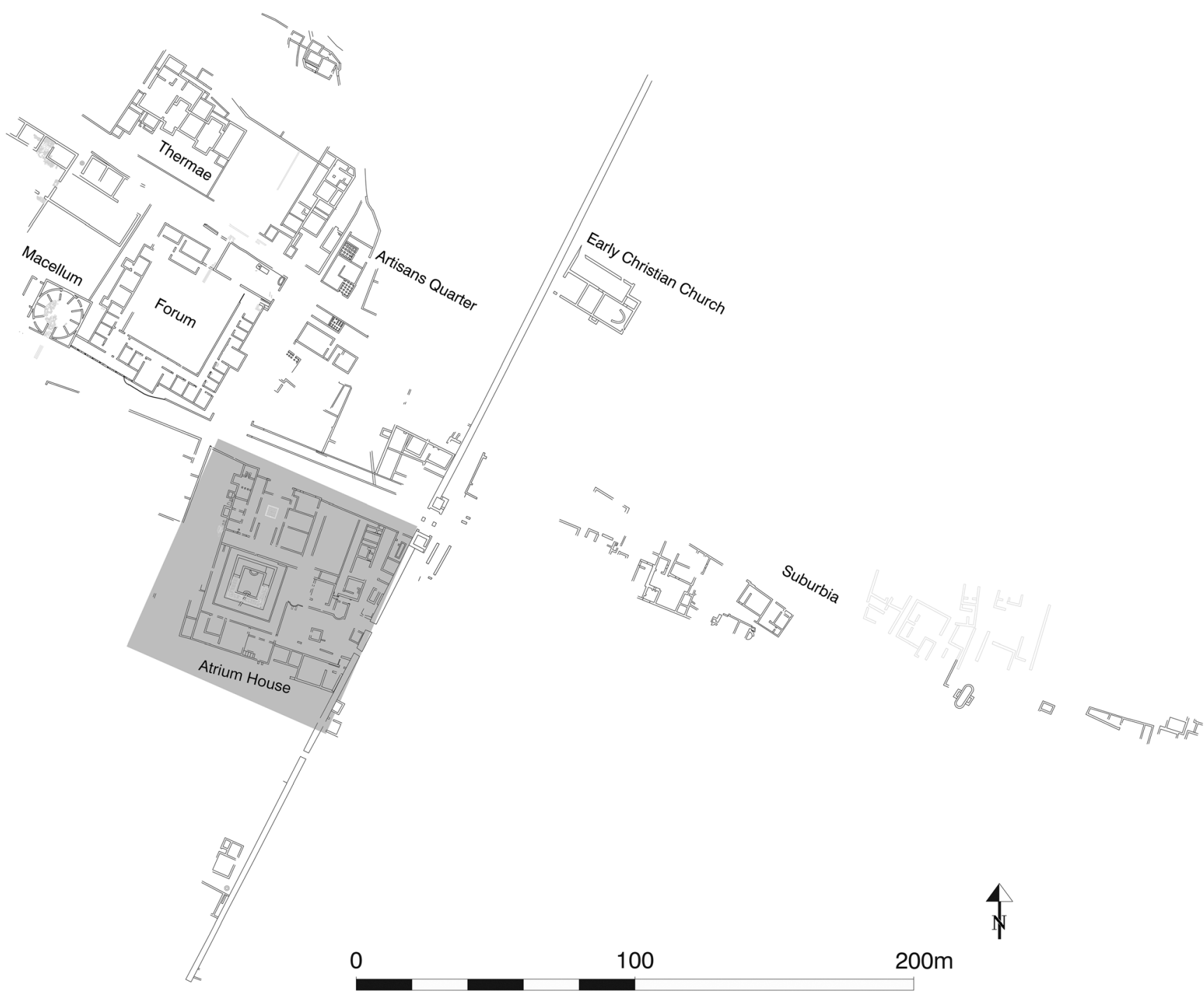

Fig. 5 Map of Roman Aguntum. The light grey structures in the suburbia are only known from ground radar measurements; black structures represent excavated walls. (Department of Archaeologies, University of Innsbruck)

Fig. 6 Aerial photograph of the Atrium House in Aguntum and its surroundings (Department of Archaeologies, University of Innsbruck)

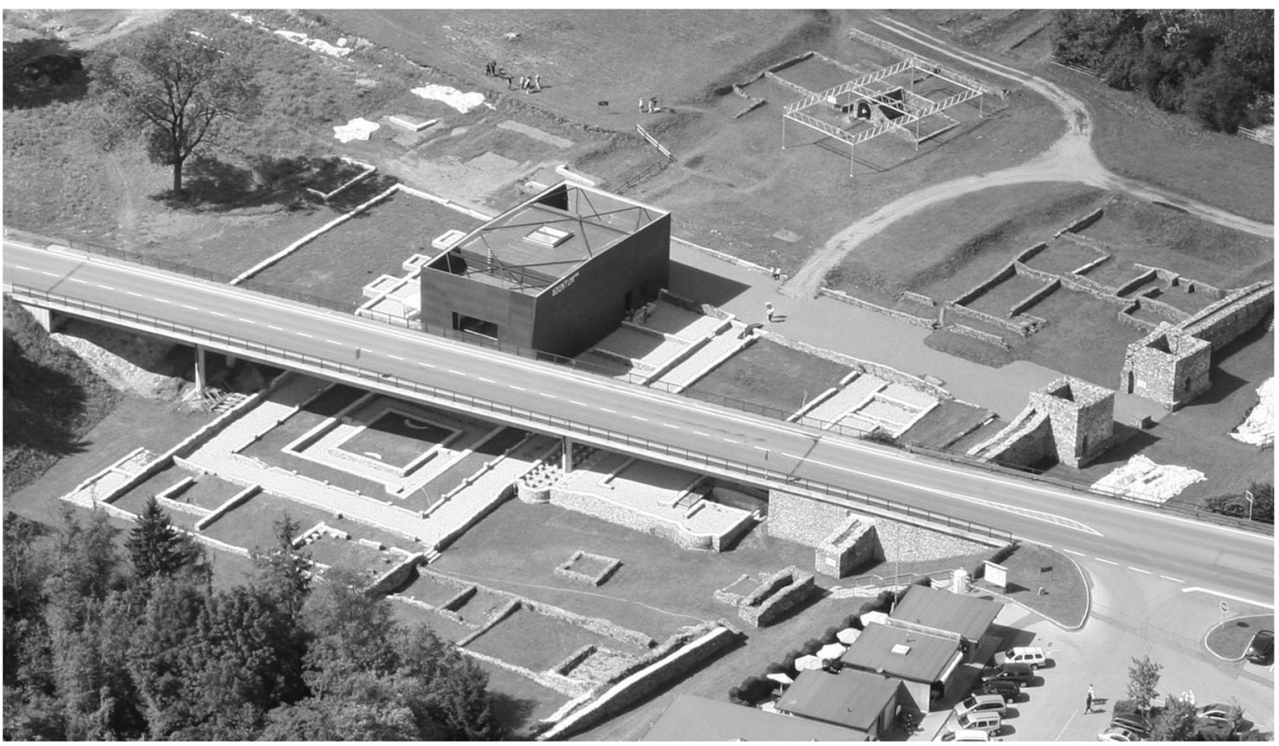




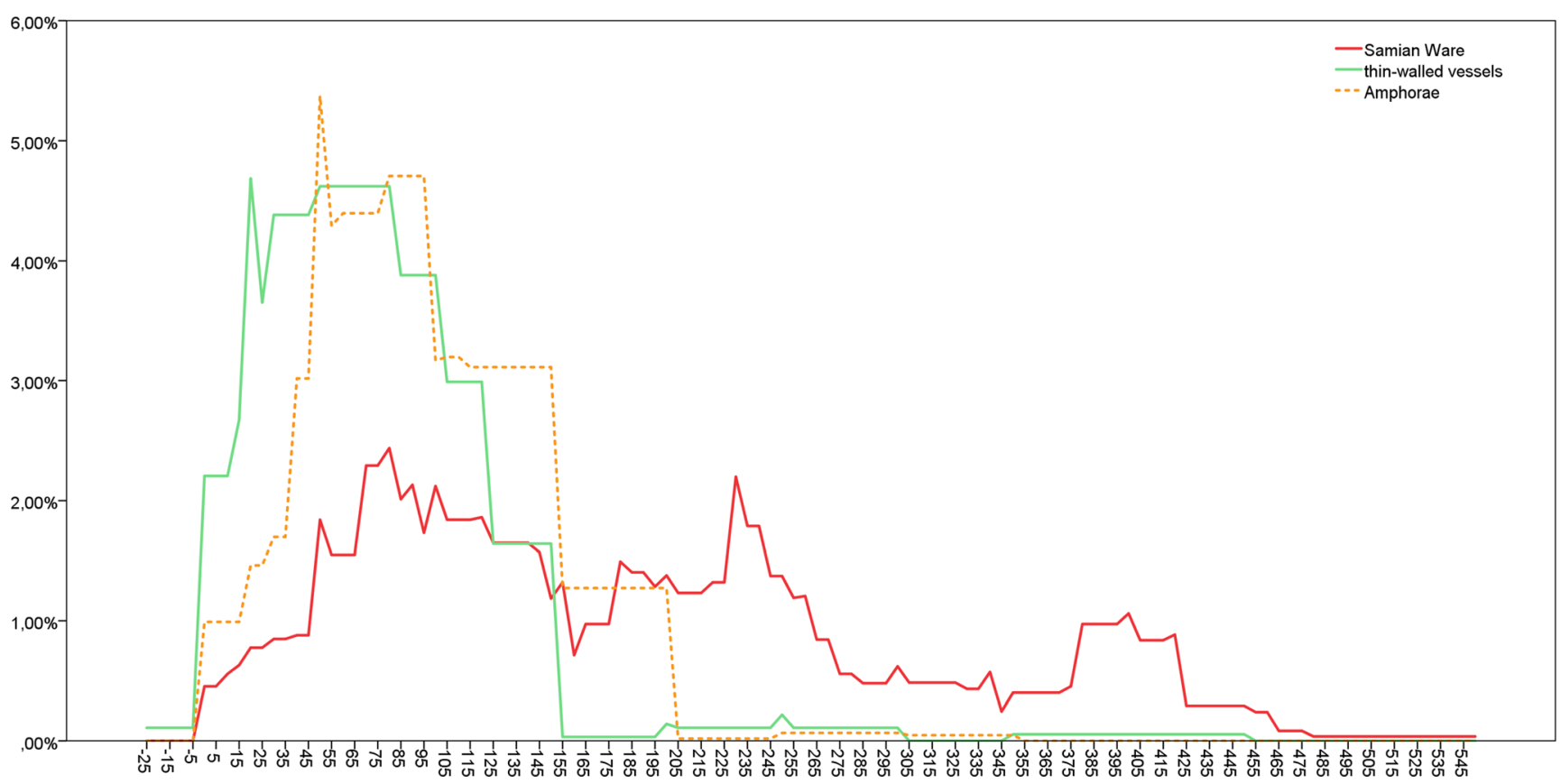

Fig. 7 Quantitative distribution of Samian Ware, thin-walled pottery and amphorae from the Atrium House (created with SPSS 23)

are clearly visible in the diagram. After a period with sparse material remains, we recognise another peak towards the end of the fourth century AD. In this period, simplified heating systems (heating channels) replaced the hypocausts in some parts of the building, but the building activity alone cannot be seen as reason for the peak around 390-400 AD. An important fact is the end of the Atrium House during the fifth century. Up to now, no findings which could be dated later than into the fifth century are known. So, this period of abandonment seems to be present in the diagram, because during the abandonment of a residential building, most of the pottery is discarded in and around the living spaces (e.g. Cameron and Tomka 1993) and the house is no longer kept clean as it is to presume for earlier times.

\section{Discussion}

The adaption of a method developed in numismatics, where it is possible to date coins very precisely for all groups of small finds lead to several problems which shall be shortly discussed. One important parameter in analysing artefacts is assigning dates to the various small finds. While for some find categories, like coins and stamped/decorated vessels, date ranges can be allocated quite precisely; others, like fibulae, might elude the assignment of a constricted production date. For the first group of findings, we are mainly dealing with production dates, whether the second group is dated by site comparison and therefore rather reflects the time span of use. This is not the place for an exhaustive discussion regarding the problems of dating artefacts based on so called dated sites (for
Samian Ware from Gaul, e.g. King 2013). In general, precise dates are, similar to numismatics, assignable to vessels with known producers, either in evidence of stamps or specific decoration. This approach was used in a similar way as presented here to date Roman Forts in the Rhine delta (Polak et al. 2012) without discussing the method in detail.

However, the approach presented in this paper is not restricted to stamped and decorated Samian Ware but does also include other groups of findings. The different types are allocated to their main production and usage ranges, resulting in a grainier but potentially still revealing resolution. Decorated Samian Ware from the >Gmeinerwiese in Bregenz highlights that the results of the quantitative analyses show a better resolution using precise dates which are provided through a synoptic consideration of material and style and occasionally even stamps. This is especially true when viewed in contrast to the more roughly dated finds from the same excavation.

Another recurring problem proved to be the time span of usage given in the literature for different types of small finds. While several finds are dated using 25- or 50-year steps, many objects are dated using the span of a reign of specific emperors. This method can result in small but nevertheless detectable increases and therefore blurring at the beginning and end of an emperor's reign. Numismatics uses the approach to halve the values at the beginning and end points of each reign period. However, when applying this approach to the $>$ Gmeinerwiese $<$ data, the graphs exhibited slight decreases, thus, leading to another blurred result. The resulting decrease most likely is related to the fact that not all finds were dated using the reign of emperors, but many finds were also dated using 25-year steps. Both date ranges, 25-/50-year steps as 
well as reign of emperors, present problems with the division into 5-year steps: When primarily working with dates like first, respectively, second half or middle of a century, artificial peaks occur at the middle of the centuries where all the dates meet. To reduce these peaks, it is advisable to divide the first half of a century into ten 5-year steps ending at 45, as well as the second half of the century beginning at 55 . This way, the peaks are flattened and the graphs show a more accurate distribution of finds at each time. However, one should be aware that abundantly clear peaks in the diagram which are limited to a single 5-year step are most likely resulting from such overlapping. The problem with dividing dates by emperor's reign into 5-year steps is given by their period of reign. Since they do not align with the 5-year steps, the dates need to be round off or round up. Dates ending in 1, 2, 6 or 7 are rounded off; those ending in 3, 4, 8 or 9 are rounded up. For example, Vespasian's period of reign dates from 69 until $79 \mathrm{AD}$, which results in five 5-year steps from 70 to $80 \mathrm{AD}$; Hadrian ruled from 117 until $138 \mathrm{AD}$ which results in six 5-year steps from 115 until $140 \mathrm{AD}$.

Further, a crucial parameter is the chronological distribution of the small finds. Each chosen find category should be represented throughout the duration of the assessed settlement or structure to gain more insight into the distribution of the finds and therefore of settlement activity, revealing increases and decreases. The number of identified specimens in each category of small finds also needs to be considered since a low number of identified specimens can lead to blurring of the results. In case of studying the material found at the \Gmeinerwiese`, it was decided to disregard the coins since only few were recovered due to the rudimentary excavation methods. Apart from the low number of encountered coins, a separate analysis revealed an unexpected peak in Claudian times which does not correlate with other observations regarding the coins from Brigantium (Rabitsch 2020). Since this peak is most likely related to the small number of coins recovered, it was decided to exclude them.

However, it should be considered that despite those minor problems, the approach still can provide important results when studying an outdated excavation.

\section{Conclusions}

In this paper, an approach on how to gain as much chronological information as possible from outdated excavations, using pottery and other small finds, is discussed. The method is easy to apply using any spreadsheet such as Microsoft Excel or IBM SPSS Statistics. As with every statistical evaluation, some parameters need to be pre-established to reduce the potential for blurry outcomes. This is especially the case, when using archaeological material with wide and rather summary dating ranges. The result of the analysis is a diagram which shows several peaks. Each major peak and/or decrease should be assessed individually, as the archaeological background can vary widely. As seen in the case studies above, peaks can result from destruction layers or intense building activity, a decrease in the diagram can relate to a real hiatus or simply to a period without building activities in the analysed area. However, as shown by the case studies, the outcome of this method displays a rough timeline of the excavated features that, if combined with other results of the analyses of the excavations, is a useful tool to gain information about the diachronic development of a site.

Acknowledgements Special thanks go out to Benjamin Wimmer who first had the idea of using this approach on unstratified small finds, and without whom, in the long run this article would not have been written. We also want to thank Katharina Blasinger and Arpad Langer who analysed the fibulae and metallic small finds, as well as coins and glass found at the so-called > Gmeinerwiese .

Funding Information Open access funding provided by University of Innsbruck and Medical University of Innsbruck.

Open Access This article is licensed under a Creative Commons Attribution 4.0 International License, which permits use, sharing, adaptation, distribution and reproduction in any medium or format, as long as you give appropriate credit to the original author(s) and the source, provide a link to the Creative Commons licence, and indicate if changes were made. The images or other third party material in this article are included in the article's Creative Commons licence, unless indicated otherwise in a credit line to the material. If material is not included in the article's Creative Commons licence and your intended use is not permitted by statutory regulation or exceeds the permitted use, you will need to obtain permission directly from the copyright holder. To view a copy of this licence, visit http://creativecommons.org/licenses/by/4.0/.

\section{References}

Brulet, R., Vilvorder, F. \& Delage, R. (2010). La céramique romaine en Gaule du Nord. Dictionnaire des céramiques. La vaisselle à large diffusion. Turnhout: Brepols Publishers

Cameron CM, Tomka SA (eds) (1993) Abandonment of settlements and regions. Ethnoarchaeological and archaeological approaches. Cambridge University Press, Cambridge

Ertel C, Kandler M (1985) Zum Modell von Brigantium. In: Vonbank E (ed) Das römische Brigantium. Ausstellungskatalog 124 . Vorarlberger Landesmuseum, Bregenz, pp 137-149

Grabher G (1994) Bregenz/Brigantium. Archäologie Österreichs 5(1): $59-66$

Hartley B, Dickinson BM (2008a) Names on Terra Sigillata. An index of makers' stamps and signatures on gallo-roman Terra Sigillata (Samian ware). Vol. 1, a to Axo. University of London Institute of Classical Studies, London

Hartley B, Dickinson BM (2008b) Names on Terra Sigillata. An index of makers' stamps and signatures on gallo-roman Terra Sigillata (Samian ware). Vol. 2, B to Cerotcus. University of London Institute of Classical Studies, London

Hartley B, Dickinson BM (2008c) Names on Terra Sigillata. An index of makers' stamps and signatures on gallo-roman Terra Sigillata 
(Samian ware). Vol. 3, Certianus to Exsobano. University of London Institute of Classical Studies, London

Hartley B, Dickinson BM (2009a) Names on Terra Sigillata. An index of makers' stamps and signatures on gallo-roman Terra Sigillata (Samian ware). Vol. 4, F to Klumi. University of London Institute of Classical Studies, London

Hartley B, Dickinson BM (2009b) Names on Terra Sigillata. An index of makers' stamps and signatures on gallo-roman Terra Sigillata (Samian ware). Vol. 5, L to Masclus I. University of London Institute of Classical Studies, London

Hartley B, Dickinson BM (2010) Names on Terra Sigillata. An index of makers' stamps and signatures on gallo-roman Terra Sigillata (Samian ware). Vol. 6, Masclus I-Balbu to Oxittus. University of London Institute of Classical Studies, London

Hartley B, Dickinson BM (2011a) Names on Terra Sigillata. An index of makers' stamps and signatures on gallo-roman Terra Sigillata (Samian ware). Vol. 7, P to Rxead. University of London Institute of Classical Studies, London

Hartley B, Dickinson BM (2011b) Names on Terra Sigillata. An index of makers' stamps and signatures on gallo-roman Terra Sigillata (Samian ware). Vol. 8, S to Symphorus. University of London Institute of Classical Studies, London

Hartley B, Dickinson BM (2012) Names on Terra Sigillata. An index of makers' stamps and signatures on gallo-roman Terra Sigillata (Samian ware). Vol. 9, T to Ximus. University of London Institute of Classical Studies, London

Heiligmann, J. (1990). Der "Alb-Limes". Ein Beitrag zur römischen Besetzungsgeschichte Südwestdeutschlands. Stuttgart: Konrad Theiss Verlag

King, A. C. (2013). Coins and Samian ware. A study of dating of coinloss and the deposition of samian ware (terra sigillata), with a discussion on the decline of samian ware manufacture in the NW provinces of the Roman empire, late $2^{\text {nd }}$ to mid $3^{\text {rd }}$ centuries AD. BAR international series 2573. Oxford: BAR publishing

Konrad, M. (1997). Das römische Gräberfeld von Bregenz - Brigantium I. Die Körpergräber des 3.-5. Jahrhunderts München: C. H. Beck

Kopf J (2011) Zur Siedlungsentwicklung Brigantiums in der späten mittleren Kaiserzeit. Jahrbuch des Vorarlberger Landesmuseumsvereins 2011:76-113

Kopf J (2015) Die frühkaiserzeitlichen Militärlager in Brigantium. In: Grabher G, Rudigier A (eds) Archäologie in Vorarlberg. Josef Fink Verlag, Lindenberg, pp 87-93

Kopf J, Oberhofer K (2014) Forschungsprojekt Bregenz Böckleareal: eine Zwischenbilanz. In: Baur C (ed) Ausgraben - Dokumentieren - Präsentieren. Jahresbericht des Instituts für Archäologien 2013. Institut für Archäologien, Innsbruck
Kopf J, Oberhofer K (2016) Demontiert, planiert und markiert: Archäologische Zeugnisse vom Ende des tiberischen Militärlagers in Bregenz. In: Grabherr G et al (eds) Der Übergang vom Militärlager zur Zivilsiedlung. Akten des internationalen Symposiums vom 23.-25. Oktober 2014 in Innsbruck. Ikarus 10. innsbruck university press, Innsbruck

Mees AW (1995) Modelsignierte Dekorationen auf südgallischer Terra Sigillata. Konrad Theiss Verlag, Stuttgart

Oswald F, Pryce TD (1920) An introduction to the study of Terra Sigillata. Longmans, Green and Co., London

Overbeck, B (1982). Geschichte des Alpenrheintals in römischer Zeit auf Grund der archäologischen Zeugnisse 1. Topographie, Fundvorlage und historische Auswertung. München: C. H. Beck

Planck, D. (1975). Arae Flaviae I. Neue Untersuchungen zur Geschichte des römischen Rottweil. Teil I. Stuttgart: Verlag Müller \& Gräff

Polak M (2000) South Gaulish terra sigillata with potters' stamps from Vechten. Katholieke Universiteit Nijmegen, Nijmegen

Polak M, Niemeijer R, van der Linden E (2012) 27 Alphen aan den RijnAlbaniana and the dating of the Roman forts in the Rhine delta. In: Bird D (ed) Dating and interpreting the past in the Western Roman empire. Essays in honour of Brenda Dickinson. Oxbow Books, Oxford, pp 266-294

Rabitsch J (2020) Gmeinerwiese 1974. Ein Beitrag zur Siedlungsgeschichte von Brigantium/Bregenz anhand der Untersuchung des nordöstlichen Siedlungsrandes. In: Lang F et al (eds) Akten des 17. Österreichischen Archäologentages an der Paris Lodron-Universität Salzburg von 26.-28. Februar 2018. Archæoplus 10. Universität Salzburg, Salzburg

Ricken H, Fischer C (1963) Die Bilderschüsseln der römischen Töpfer von Rheinzabern. In: Textband mit Typenbildern zu Katalog VI der Ausgrabungen von Wilhelm Ludowici in Rheinzabern 1901-1914. Rudolf Habelt Verlag, Bonn

Stanfield JA, Simpson G (1958) Central Gaulish potters. Oxford University Press, London

Tschurtschenthaler M (2005) Municipium Claudium Aguntum. Wohnluxus in den Alpen. In: Dal Ri L, di Stefano S (eds) Littamum. Una mansio nel Norico / Eine Mansio in Noricum. British archaeological reports, international series, vol 1462. Hadrian books, Oxford, pp 105-126

Tschurtschenthaler M, Auer M (2013) 100 Jahre wissenschaftliche Ausgrabungen in Aguntum. Osttiroler Heimatblätter 81:1-6

Vondrovec K (2005) Der numismatische Fingerabdruck. Mitteilungen der Österreichischen Numismatischen Gesellschaft 45(3):176-195

Publisher's note Springer Nature remains neutral with regard to jurisdictional claims in published maps and institutional affiliations. 